peutic doses of warfarin: here single, small doses of vitamin $K_{1}$ are often sufficient.

Department of Hæmatology, Guy's Hospital, London SE1 9RT

MARTIN J. SHEARER Percy Barkhan

\section{MISDIAGNOSES OF ENDOGENOUS DEPRESSION WITH RESEARCH DIAGNOSTIC CRITERIA}

SIR,-Dr Nelson and colleagues, ${ }^{1}$ commenting on their experience with the research diagnostic criteria (R.D.C.) ${ }^{2}$ for the diagnosis of major depressive disorder (M.D.D.), primary subtype, drew attention to the problem of false-positive diagnoses, which they ascribe to their use of the criteria exactly as written. If the R.D.C. are used in a "mere checklist fashion" a distinctly heterogeneous group of patients is identified. Alternatively an investigator can interpret the diagnostic criteria in the light of his clinical judgment, and so narrow the group of patients. One method of use raises questions about the usefulness of the R.D.C., the other, questions about their objectivity.

We agree with the need for caution, and would add that the R.D.C. are similarly flawed for the endogenous subtype of M.D.D.. For research purposes this is a more critical issue than the validity of the general category M.D.D.: the Washington University group acknowledge that their criteria ${ }^{3}$ (which formed the basis for the R.D.c.) mix together endogenous and neurotic depressions. ${ }^{4}$ That is essentially the point made by Nelson et al.

The endogenous subtype of M.D.D., however, was proposed for "those subjects who show a particular symptom picture that many research studies indicate is associated with good response to somatic therapy". ${ }^{2}$ These are also the patients for whose depression a biological basis is commonly speculated. Both we and Spitzer et al. ${ }^{2}$ use the diagnosis as elaborated by Klein" with his term "endogenomorphic depression".

We have compared the R.D.C. for endogenous M.D.D. with our own clinical diagnoses in 48 consecutive outpatients presenting to our affective-disorders clinic with a complaint of depressed mood. All patients were seen by a psychiatrist in an open clinical interview lasting an hour or more and by a clinical social worker who administered the schedule for affective disorders and schizophrenia. ${ }^{6}$ When possible, a family member or some other significant person was seen in an adjunctive interview. Initial clinical and R.D.c. diagnoses were made on the basis of this information. The clinical diagnoses were reviewed and revised on the basis of follow-up information gathered six months to two years later. Follow-up diagnoses were based on response to treatment, other aspects of the clinical course, and information from the patients' current therapist if we were no longer seeing the patient. Patients were classified as having endogenous depression or some other diagnosis both on clinical criteria and on R.D.C. criteria. This led to the four-fold table shown below. The R.D.C. led to both false-positive and falsenegative errors, with $30 \%$ of patients classified incorrectly. Cohen's kappa ${ }^{7}$ was 0.41 , indicating poor agreement between the clinical and R.D.C. diagnoses. ${ }^{8}$ Of the six patients incorrectly classed as not endogenously depressed by the R.D.C. (false negatives), 3 were bipolar, with unequivocal episodes of mania or hypomania meeting R.D.C. criteria. The 8 false-posit-

1 Nelson, J. C., Charney, D. S., Ving1ano, A. W. Lancet, 1978, 11, 1252.

2 Spıtzer, R. L., Endicott, J., Robins, E. Research Diagncstıc Criteria. Bımetrics Research, New York State Department of Mental Hygiene, 1975

3. Feighner, J. P., Robins, E., Guze, S. B., Woodruff, R. A., Winokur, G., Munoz, R. Archs gen. Psychiat. 1972, 29, 57.

4 Woodruff, R A., Jr., Goodwin, D. W., Guze, S. B. Psychiatric Diagnosis p. 6 New York, 1974.

5 Kleın, D. F. Archs. gen. Psychiat. 1974, 31, 447

6 Spizer, R. L., Endicott, J. Schedule for Affective Disorders and Schizophrenia. Biometrics Research, New York State Psychiatric Instıtute, 1975. Cohen, J. Educ. Psychol.Measmt, 1960, 20, 37.

8 Spizer, R. L., Fleiss, J. L., Endicott, J. in Psychopharmacology: a generation of progress (edited by M. A. Lipton, A. DiMascio, and K. F. Killam, New York, 1978
RESULTS OF A STUDY OF 48 PATIENTS, COMPARING R.D.C. DIAGNOSES AT INTAKE WITH CLINICAL DIAGNOSIS AFTER TREATMENT AND FOLLOW-UP

\begin{tabular}{l|c|c|c}
\hline \multirow{2}{*}{$\begin{array}{c}\text { R.D.C. } \\
\text { diagnosis }\end{array}$} & $\begin{array}{c}\text { Clinical diagnosis } \\
\text { Endogenous } \\
\text { depression }\end{array}$ & Other & Total \\
\hline $\begin{array}{l}\text { Major depressive } \\
\text { disorder, endogenous }\end{array}$ & $\begin{array}{c}15 \\
\text { (true +ve) }\end{array}$ & $\begin{array}{c}8 \\
\text { (false +ve) }\end{array}$ & 23 \\
\hline Other & 6 & 19 & 25 \\
\hline Total & 21 & 27 & 48 \\
\hline
\end{tabular}

ives were patients with atypical dysphoric presentations, whose symptom profiles were widely divergent from the "coherent syndrome" ordinarily recognised as endogenous depression.

We will not discuss in detail here the reasons why we think the R.D.C. are inadequate per se for the diagnosis of endogenous depression. The important points are that a considerable refinement of the R.D.C. is needed, and that the R.D.C. do not perform as supposed in identifying homogeneous groups of patients for research. In fact, no "mere checklist" of clinical features can be expected to select a completely homogeneous group of patients. A diagnosis, even though generated by "research" criteria, is nothing more than a statement of probability, which needs to be viewed in the light of clinical judgment and commonsense.

Mental Health Research Institute, University of Michigan,

Ann Arbor, Michigan, 48109, U.S.A.

Michael Feinberg

Bernard J. Carroll Meir Steiner

ANNE J. COMMorato

\section{WHO SHOULD MEASURE THE BLOOD-PRESSURE?}

SIR,-I read your editorial (Jan. 20, p. 137) with great interest.

It is a relief to see that the concept of home blood-pressure measurement, promoted for so long by enthusiasts, ${ }^{1-4}$ has at last obtained a measure of popular acceptance. Published work from my department ${ }^{5}$ has clearly shown that patients can learn to take their own blood-pressures without neurotic obsessions developing, and often find it helpful in the management and understanding of their condition. However, there is need for a certain caution when it comes to chemist's shop sphygmomanometers. These semiautomatic instruments are often very inaccurate $^{6-9}$ and do not always over-read, as your editorial suggests. The instrument reported in the National Press has been evaluated in my department and found to be very unpredictable in this respect.

Home blood-pressures seldom tally closely with clinic recordings. ${ }^{4}$ On the contrary, clinical readings tend to be much higher, particularly with respect to systolic pressure, and it remains to be determined which type of measurement has the greater prognostic significance in large-scale studies.

Northwick Park Hospital

and Clinical Research Centre,

Harrow, Middlesex HA1 3UJ

E. B. RAFTERY

1. Gordon, R. D., Pawsey, C. G. K., O'Halloran, M. W., Abott, H. L., Wilson, L. L., Silverstone, H. Med. F. Aust. 1971, ii, 565.

2. Julius, S., Ellis, C. H., Pascual, A. V., Matice, M., Hansson, L., Hunyor, S. N., Sandler, L. N. F. Am. med. Ass. 1974, 229, 663.

3. Lancet, $1975, \mathrm{i}, 259$.

4. Raftery, E. B. in Hypertension: its nature and treatment; p. 219. Ciba Laboratories, 1974.
Laftery, E. B. in Hypert

5. Wilkinson, P. R., Raftery, E. B. Br. med. F. 1978, 1, 1824

6. Hunyor, S. N., Flynn, J. M., Cochineas, C. ibid. 1978, ii, 159

7. Lancet, $1976, \mathrm{ii}, 409$.

8. Raftery, E. B. Br. F. clin. Pharmac. 1978, 6, 193.

9. Edwards, R. C., Goldberg, A. D., Bannıster, R., Raftery, E. B. Lancet, 1976, ii, 398 . 